\title{
APLIKASI ANALISIS BIOMEKANIKA (KINOVEA SOFTWARE) UNTUK MENGEMBANGKAN KEMAMPUAN LARI JARAK PENDEK (100 M) MAHASISWA PJKR UNSUR
}

\author{
Adi Rahadian \\ Universitas Suryakancana \\ email : adira@unsur.ac.id
}

\begin{abstract}
Abstrak
Penelitian ini dilakukan untuk mengetahui kemampuan kecepatan lari 100 meter. Penelitian ini, dimaksudkan untuk mengetahui analisis kecepatan setiap per 10 meter. Lari 100 meter dengan sistem energi anaerobik laktit perlu pola strategi atau pengaturan kecepatan untuk mendapatkan prestasi terbaik. Penelitian ini adalah penelitian survey. Populasi dalam penelitian ini yaitu Mahasiswa Tingkat I PJKR FKIP UNSUR. Teknik pengambilan data menggunakan purposive sampling, sampel yang didapatkan sejumlah 10 orang. Data yang diperoleh berupa video dan analisis data menggunakan kinovea software. Hasil penelitian menunjukkan bahwa pelari dapat melakukan percepatan (akselerasi) pada jarak 0-50 meter dengan nilai rata-rata percepatan (akselerasi) yang dilakukakn pelari yaitu $1.23 \mathrm{~m} / \mathrm{s}$, dan pelari kembali melakukan percepatan pada jarak 8090 meter dengan nilai rata-rata percepatan (akselerasi) yang dilakukan pelari yaitu 1.23 $\mathrm{m} / \mathrm{s}$.
\end{abstract}

Kata kunci: analisis biomekanika, kemampuan lari, kinovea software

\begin{abstract}
This research was conducted to determine the ability of 100 meters running speed. This study, is intended to determine the speed analysis per 10 meters. Running 100 meters with a lactite anaerobic energy system needs a strategy pattern or speed regulation to get the best performance. This research is survey research. The population in this study were Level I PJKR Students FKIP UNSUR. The data collection technique uses purposive sampling, the sample obtained is 10 people. Data obtained in the form of video and data analysis using kinovea software. The results showed that runners can accelerate at a distance of 0-50 meters with acceleration values that are runners namely $1.23 \mathrm{~m} / \mathrm{s}$, and runners do acceleration at a distance of 80-90 meters with an average value of the acceleration (acceleration) carried out by the runner is $1.23 \mathrm{~m} / \mathrm{s}$.
\end{abstract}

Keywords: biomechanical analysis, running ability, kinovea software 


\section{PENDAHULUAN}

Olahraga adalah sebuah
kegiatan yang mengutamakan
pengolahan fisik. Olahraga juga
merupakan salah satu media untuk
membuat kondisi kesehatan manusia
menjadi lebih baik dan terjaga. Cabang atletik adalah cabang yang menjadi dasar dari semua cabang olahraga lainnya. Karena bagianbagian dari atletik dipergunakan dalam cabang olahraga lain, seperti lari, lompatan, dan lemparan. Dalam cabang olahraga lari terdapat beberapa cabang lagi, seperti lari dengan jarak 100 meter, 200 meter, dan 400 meter. Cabang-cabang olahraga ini adalah cabang olahraga yang sangat populer dan selalu diperlombakan di ajang-ajang lomba internasional.

Dalam cabang olahraga atletik sangat mengutamakan kecepatan, karena kemenangan dalam cabangcabang ini adalah jika perlari berhasil mencetak waktu yang lebih kecil dari lawan-lawannya, dengan kata lain seorang pelari harus terlebih dahulu sampai ke garis finish daripada lawan-lawannya. Untuk mendapatkan kecepatan tidaklah mudah, karena banyak faktor-faktor pendukung untuk mendapatkan kecepatan maksimum dari lari seorang atlet.

Gerakan lari sprint dalam menggunakan ujung-ujung kaki untuk menapak, sedangkan tumit tidak menyentuh tanah pada permulaan dari tolakan kaki sampai masuk garis finish, sebagaimana dijelaskan Munasifah dalam Ismail (2014 : 17) yang harus diperhatikan juga adalah berat badan pelari harus selalu berada sedikit di depan kaki pada waktu menapak, atau dalam posisi badan condong ke depan.
Salah satu faktor pendukung atlet untuk mendapatkan kecepatan maksimum adalah seorang atlet harus memiliki teknik berlari yang baik. Pembentukan teknik berlari yang baik, bisa didapat dengan menjalani latihan secara berkelanjutan, pengawasan dari staff ahli, serta dengan bantuan analisis biomekanik. Dengan kemajuan teknologi analisis biomekanika bisa dilakukan dengan bantuan komputer.

Analisis biomekanika yang dilakukan menggunakan komputer biasanya dilakukan dengan meneliti hasil rekaman sesi latihan atau pertandingan yang dilakukan oleh atlet. Dari hasil analisis biomekanik, data yang didapat berupa kecepatan atlet, sudut-sudut sendi atlet pada saat berlari. Hasil analisis tersebut yang menentukan apakah atlet sudah memiliki teknik berlari yang baik atau tidak. Namun seberapa besar kontribusi dalam pencapaian tersebut belum dapat dipastikan. Apakah panjang langkah seseorang mendominasi keberhasilan pencapaian waktu tersingkat dalam lari sprint. Hal ini dikarenakan keadaan kaki adalah yang utama dalam pencapaian hasil gerakan yang maksimal yang didukung oleh analisis biomekanika menggunakan aplikasi berbasis sport science. Sesuai dengan judul, “Aplikasi Analisis Biomekanika Untuk Mengembangkan Kemampuan Lari Jarak Pendek Mahasiswa PJKR UNSUR (Kinovea Software)”.

\section{BAHAN DAN \\ METODE/METODOLOGI}

Pada abad modern ini kemajuan teknologi dalam semua bidang cabang ilmu sudah menjadi bagian yang tidak terpisahkan. Begitu juga kemajuan teknologi dalam bidang olahraga yang sudah 
sangat berkontribusi dalam peningkatan pembelajaran dan performa prestasi atlet. Pengunaan teknologi sebagai salah satu upaya untuk meningkatkan prestasi dalam olahraga sudah dilakukan di negaranegara maju di Asia seperti Jepang, China dan Australia.

Hal ini terbukti dengan adanya berbagai laboratorium ilmu keolahraga antara lain di Jepang ada JISS (Japan Institute of Sport Science), di Australia ada AISS (Australia Institute of Sport Science), di China ada BISS (Bejing Iinstitute of Sport Science) dan banyak di negera lainnya, dilaboratorium ini para pakar berbagai keilmuan bersatu dan berkolaborasi untuk mengdiagnosa, mengevaluasi, memberikan masukan keilmuan kepada pelatih dan atlet tentang segala kekurangan dan kelebihan baik atlet sendiri maupun lawan yang lebih tinggi levelnya.

Kecepatan sebagai salah satu komponen kondisi fisik yang sangat penting kini pengukurannya sudah mengunakan alat-alat teknologi yang canggih. Contohnya sensor yang ditempelkan di sepatu atlet ( Foot Pod, Polar dan Suunt ), Global Positioning System (GPS) dan Differential Global Positioning System (DGPS). selaian itu ada juga radar, photo finish, kinematic analysis, photocells dan optojump (OJ). Dolenec (2009:17) yang biasanya digunakan untuk mengukur kecepatan saat berlari. Semua alat ini dibuat untuk untuk mendiagnosa, mengevaluasi dan menganalisis performa atlet untuk peningkatan prestasinya.

Pada cabang olahraga atletik yaitu lari jarak pendek peran alat-alat tersebut sangat penting untuk analisis kecepatan lari seorang atlet.
Kontribusi dari analisis kecepatan lari terutama lari jarak pendek sangat diperlukan sekali untuk melakukan penelitian dan evaluasi atlet. Sebagai contoh bentuk dari analisis lari jarak pendek diantaranya adalah untuk mengetahui berapa kecepatan maksimal pelari tersebut, mengetahui dijarak keberapa kecepatan maskimal terjadi, mengetahui didetik berapa kecepatan maksimal terjadi, mengetahui daya tahan kecepatan atlet tersebut dan lain sebagainya.

Selain itu permasalahan yang terjadi dalam pengukuran kecepatan lari saat ini masih mengunakan alat pengukur watku dan kecepatan manual yaitu dengan mengunakan stopwatch. Pengunaan stopwatch menjadi masalah dalam keakuratan data yang dimabil karena adanya perbedaan selang waktu dalam penekanan tombol. Sehingga dapat banyak menimbulkan kesalahan (human error) karena tingkat repleks dan kepekaan manusia berbeda-beda. Sehingga Perlu adanya suatu sistem alat penentu waktu dan kecepatan pelari yang otomatis (Hadi, detikSport.com).

Biomekanika adalah studi tentang fungsi dan strukutural sistem biologi dengan menggunakan metode mekanik. Pendekatan biomekanika terhadap olahraga lebih difokuskan kepada pelaku olahraga (atlet), tetapi pendekatan biomekanika terhadap olahraga juga bisa merambah kepada perilaku objek yang tidak bergerak seperti alas kaki, permukaan (field), dan perlengkapan olahraga yang dapat mempengaruhi performa atlet.

Hal ini sangat didukung oleh pernyataan Pate dkk (1984 : 2), bahwa biomekanika olahraga memberikan penjelasan mengenai pola - pola gerakan yang efisien dan efektif para olahragawan, misalnya 
para ahli biomekanika telah menggunakan fotografi berkecepatan tinggi untuk mempelajari pola - pola gerakan pitcher baseball yang berhasil.

Hasil penelitian semacam itu memberikan informasi yang dapat digunakan untuk menyempurnakan teknik olahragawan mereka. Pemikiran yang sama juga telah dituangkan Pate dkk (1984 : 3) mengenai penggunaan teknologi komputer yaitu, penerapan teknologi komputer pada biomekanika kemungkinan besar dapat menambah secara besar - besaran jumlah penelitian keolahragaan di tahun tahun mendatang.

Menurut Crespo, et. al (2002: 20) pelatih harus memperhatikan fakta bahwa perkembangan pertumbuhan umur atlet dapat berbeda-beda, maka dalam hal ini pelatih bisa mengamati atletnya secara biomekanika. Dari penjelasan tadi maka kegunaan biomekanika bagi pelatih: (1) pengetahuan biomekanika membantu para pelatih menganalisa suatu keterampilan, (2) biomekanika membantu dalam menilai teknik-teknik baru dan latihan baru, (3) biomekanika membantu memperkecil atau mencegah cidera yang di akibatkan oleh gerakan, (4) biomekanika membantu menciptakan teknikteknik baru dalam menampilan suatu keterampilan yang menghasilkan efektivitas yang lebih tinggi.

\section{Metode Dan Desain Penelitian}

Metode yang digunakan dalam penelitian ini adalah penelitian survei dengan teknik observasi berdasarkan literatur. Hasil rekaman (visual) dengan dokumentasi menggunakan kamera. Dokumentasi yang dilakukan untuk merekam teknik gerakan lari yang dilakukan oleh atlet lari pada saat latihan yang kemudian akan dianalisis melalui program "kinovea software versi 0.7.10”. Dalam pelaksanaan penelitian ini menggunakan analisis cinematography dua dimensi dengan menggunakan sistem analisis perangkat lunak kinovea software versi 0.7.10.

Desain penelitian ini menggunakan desain deskriptif evaluatif. Adapun alasan menggunakan metode deskriptif evaluatif yaitu untuk memahami secara mendalam teknik gerakan lari yang dilakukan oleh atlet agar pada saat pertandingan atlet betul-betul dapat menggunakan teknik gerak tersebut secara baik dan benar.

Metode penelitian untuk membuat aplikasi analisis biomekanik ini dilakukan dengan cara melakukan analisis terhadap permasalahan inti, dan kemudian dilanjutkan dengan membuat perancangan untuk memecahkan masalah tersebut.

\section{Waktu Dan Tempat Penelitian}

Pelaksanaan penelitian analisis biomekanika bertempat di Kampus Universitas Suryakancana, Jl. Pasir Gede Raya Cianjur pada semester genap 2017.

\section{Populasi Dan Sampel}

Populasi dalam penelitian ini adalah Mahasiswa Tingkat I PJKR FKIP UNSUR yang berjumlah 10 orang. Teknik pengambilan sampel dengan teknik purposive sampling, yaitu (1) Mahasiswa dengan kecepatan waktu terbaik, (2) berjenis kelamin laik-laki. Berdasarkan 
kriteria tersebut diperoleh sampel penelitian sebanyak 10 pelari lakilaki.

\section{Teknik Pengumpulan Data Dan Teknik Analisis Data}

Metode yang digunakan dalam penelitian ini adalah metode penelitian survei dengan teknik observasional. Teknik pengamatan atau observasi dalam hal ini pengambilan videotape. Data dianalisis dengan menggunakan sistem analisis perangkat lunak kinovea video analysis software. Video rekaman dimasukkan pada sebuah laptop yang telah diinstal software kinovea video analysis software.

Pada dart trainer menawarkan rangkaian lengkap peralatan analisis video meliputi simulcam dan stromotion yang menjadikan tahapan-tahapan gerakan saat kecepatan lari 100 meter dapat dilihat dengan jelas dan rinci. Selanjutnya video lari 100 meter diubah dalam bentuk gambar perbagian, dari bagian-bagian gambar tersebut didapatkan waktu 10 meter saat atlet memasuki tanda jarak 10 meter. setelah didapatkan catatan waktu kemudian data dideskripsikan dalam hasil penelitian.

\section{HASIL DAN PEMBAHASAN}

Pada hasil penelitian dan pembahasan akan dikemukakan overview secara keseluruhan dari analisa aplikasi kinovea software. Analisa aplikasi kinovea software yang sedang berjalan menjelaskan tentang bagaimana proses proses gerak terencana dalam teknik lari jarak pendek berdasarkan langkah kaki dan kecepatan lari.

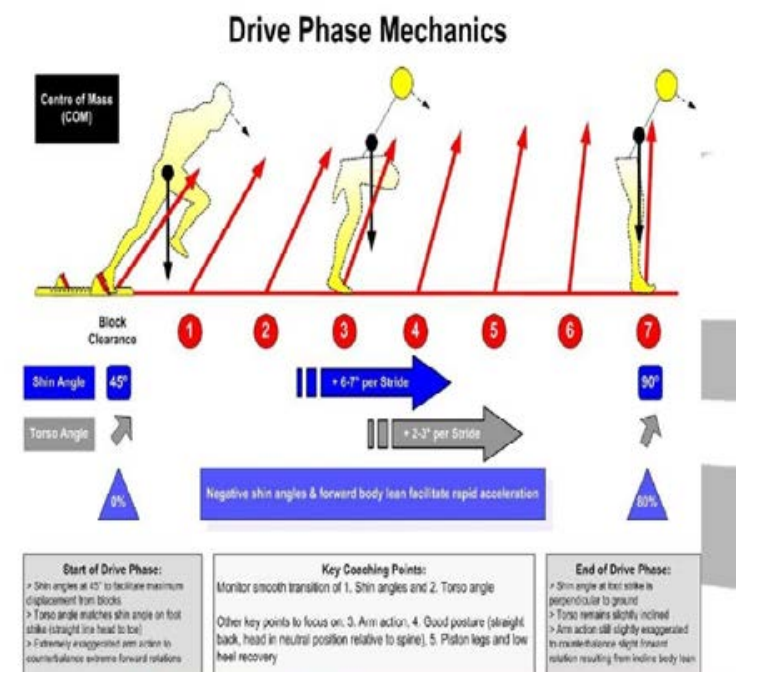

Gambar 1. Drive Phase Mechanics

Tugas pelari selama fase ini adalah melakukan dorongan ke arah bawah dan belakang terhadap tanah. Dorongan ini, disebabkan oleh ekstensi yang kuat dari sendi panggul, lutut, dan pergelangan kaki, yang menyebabkan tubuh diproyeksikan ke depan dan atas menuju langkah selanjutnya.

Kecepatan pelari saaat kakinya meninggalkan tanah (yaitu panjang langkah yang harus dibuat) merupakan fungsi dari usaha (work) yang dilakukan oleh otot-otot ekstensor sendi panggul, lutut, dan pergelangan kaki selama fase ini (hubungan usaha-energi).

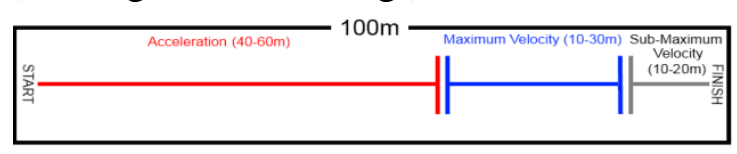

Gambar 2. Lintasan Lari Jarak

Pendek 100 meter

Instrumen pengukur kecepatan lari jarak pendek 100 meter berbasis analisa aplikasi kinovea software memiliki fungsi, yaitu dapat bekerja menghitung waktu dan kecepatan lari jarak pendek 100 meter pada setiap jarak (lini). Selain fungsi yang telah 
disebutkan, terdapat beberapa fungsi lainnya terutama dalam hal menganalisis kecepatan lari jarak pendek 100 meter diantaranya dapat mengetahui kecepatan lari, kecepatan maksimal, penurunan percepatan (deselarasi), dam daya tahan kecepatan.

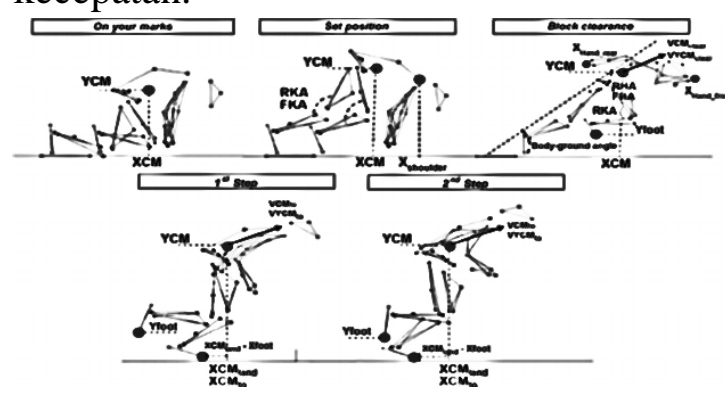

Gambar 3. Mekanika gerak lari (sprint) 100 meter

Benda mengalami gerak anguler bila dalam waktu yang sama bergerak menempuh sudut yang sama dan arah yang sama. Dalam hal ini pelari berkaitan dengan beberapa fungsi tersebut bahwa hasil dari pengukuran kecepatan lari menggunakan instrumen pengukur kecepatan lari jarak pendek 100 meter berbasis analisa aplikasi kinovea software ini akan sangat membantu untuk dapat mengevaluasi pelari guna mencapai performa terbaik pelari.

Berikut mengenai hasil penelitian kecepatan pelari lari jarak pendek $100 \mathrm{~m}$ :

Tabel 1 Hasil Raihan Waktu atau Kecepatan Lari 100 m

\begin{tabular}{ccccc}
\hline No & $\begin{array}{c}\text { Subje } \\
\mathrm{k}\end{array}$ & $\begin{array}{c}\text { Jarak } \\
(\mathrm{m})\end{array}$ & $\begin{array}{c}\text { Wakt } \\
\mathrm{u} \\
(\mathrm{m} / \mathrm{s})\end{array}$ & $\begin{array}{c}\text { Peringka } \\
\mathrm{t}\end{array}$ \\
\hline 1 & $\mathrm{~A}$ & 100 & 13.2 & 2 \\
\hline 2 & $\mathrm{~B}$ & 100 & 13.5 & 9 \\
\hline 3 & $\mathrm{C}$ & 100 & 13.65 & 10 \\
\hline 4 & $\mathrm{D}$ & 100 & 13.34 & 5 \\
\hline
\end{tabular}

\begin{tabular}{ccccc}
\hline 5 & $\mathrm{E}$ & 100 & 13.33 & 4 \\
\hline 6 & $\mathrm{~F}$ & 100 & 12.91 & 1 \\
\hline 7 & $\mathrm{G}$ & 100 & 13.32 & 3 \\
\hline 8 & $\mathrm{H}$ & 100 & 13.46 & 8 \\
\hline 9 & $\mathrm{I}$ & 100 & 13.41 & 7 \\
\hline 10 & $\mathrm{~J}$ & 100 & 13.37 & 6 \\
\hline
\end{tabular}

Dari hasil penelitian didapatkan raihan waktu tercepat yaitu $12.91 \mathrm{~m} / \mathrm{s}$ dan waktu terlambat yaitu $13.65 \mathrm{~m} / \mathrm{s}$.

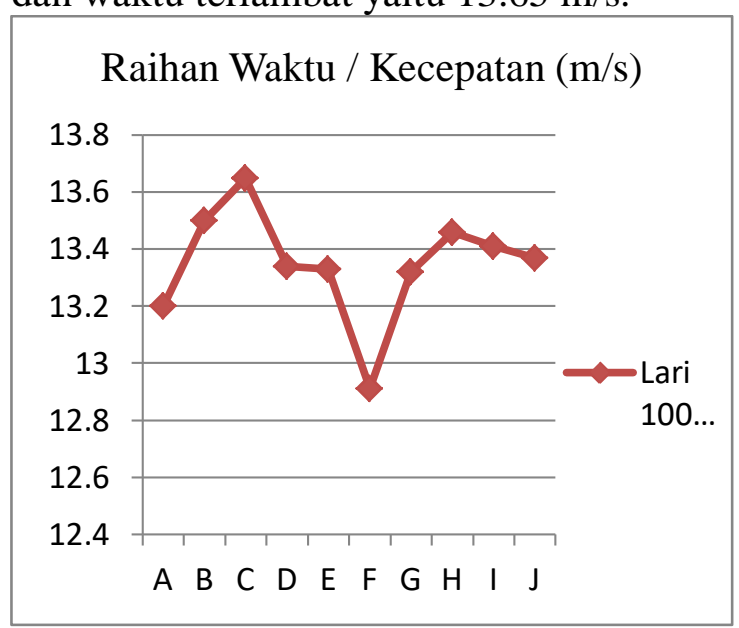

Gambar 4. Grafik Raihan

Waktu/Kecepatan Lari 100 meter

Keseluruhan rangkuman grafik kecepatan lari 100 meter dapat dilihat dengan jelas percepatan, kecepatan, dan perlambatannya, sehingga dapat diketahui naik dan turunnya kecepatan lari 100 meter. Berdasarkan gambar 4.4. diatas dapat dilihat bahwa menunjukkan percepatan lari hanya terjadi satu kali pada jarak 0-100 meter kemudian pelari cenderung memelihara kecepatan maksimalnya sampai finish. Analisis kecepatan lari belum bisa memaksimalkan lari percepatan dengan baik, karena normalnya lari percepatan hanya dapat dilakukan setelah pelari melakukan tahapan dorongan start.

Setelah mencapai kecepatan maksimalnya pelari tidak dapat memelihara atau mempertahankan kecepatan, dan cenderung mengalami 
penurunan kecepatan yang signifikan. Data diatas dapat disampaikan bahwa ada dua faktor yang mempengaruhi pola kecepatan lari pelari yaitu: (1) Komponen biomotor daya tahan kecepatan yang kurang baik, sehingga perlu dilatihan daya tahan kecepatan, sehingga pelari dapat memelihara kecepatan maksimalnya dengan baik dan tidak terjadi dua kali percepatan. (2) Teknik lari, rata-rata pelari lari dengan kecepatan tinggi yaitu lari pada lintasan lurus.

Berikut mengenai hasil penelitian kecepatan pelari lari jarak pendek $100 \mathrm{~m}$ :

\begin{tabular}{|c|c|c|c|c|c|c|c|c|c|c|c|c|c|c|}
\hline \multirow{2}{*}{$\mathbf{M}_{0}$} & \multirow{2}{*}{$\begin{array}{c}\text { Jank } \\
\text { (in) }\end{array}$} & \multicolumn{10}{|c|}{ Cutan Waknu Percepata (n/s) } & \multirow{2}{*}{$\mathrm{Rut}^{2}$} & \multirow{2}{*}{ Jin } & \multirow{2}{*}{ Ilar } \\
\hline & & A & $B$ & $\mathrm{C}$ & D & I & $\mathrm{I}$ & $G$ & H & 1 & $\mathrm{~J}$ & & & \\
\hline 1 & $0-10$ & 1.66 & 1.75 & 1.85 & 1.68 & 177 & $16 ?$ & $1.6 ?$ & 1.78 & 1.83 & 1.77 & 1.73 & 16 ? & 185 \\
\hline$?$ & $10-20$ & 1.41 & 1.49 & 1.45 & $1, A 1$ & L.4! & $1.4 !$ & $1.4 \mathrm{l}$ & $1, A]$ & 1.Al & 1.4! & 14: & 1.A] & L.49 \\
\hline 3 & $20-30$ & 1.3 & 1.26 & 133 & 1.33 & 133 & 1.3 & 1.3 & 1.23 & 1.23 & 123 & 124 & 1.3 & 133 \\
\hline 4 & $30-40$ & 1.27 & 1.28 & 1.24 & 126 & 197 & 124 & 1.28 & 1.25 & 1.27 & 128 & 126 & 1.24 & 128 \\
\hline 5 & $40-50$ & 1.3 & 1.25 & 1.97 & 1.29 & 133 & 1.5 & 1.27 & 1.29 & 1.23 & 1.25 & 1.26 & 1.3 & 129 \\
\hline 0 & $50-60$ & 133 & 135 & 137 & 139 & 133 & 1.21 & 137 & 139 & 133 & 135 & 134 & 1.21 & 139 \\
\hline 0 & $60-70$ & 1.3 & 1.5 & 1.27 & 129 & 125 & 1.3 & 1.27 & 1.29 & 1.33 & 125 & 126 & 1.3 & 129 \\
\hline 8 & $70-80$ & 134 & 135 & 1.34 & 134 & 134 & 1.24 & 134 & 1.34 & 134 & 134 & 133 & 1.24 & 135 \\
\hline 9 & $80-90$ & 1.3 & 1.26 & 1.29 & 133 & 126 & 1.3 & 1.9 & 1.26 & 1.26 & 123 & 1.5 & 1.3 & 129 \\
\hline 10 & $90 \cdot 100$ & 1.28 & 1.26 & 1.24 & 122 & 128 & 1.5 & 1.24 & 1.2 .2 & 1.28 & 126 & 1.5 & 1.2 & 128 \\
\hline & E & 132 & 13.5 & 1365 & 1334 & 13.33 & 1291 & 1332 & 13.46 & 1341 & 1337 & 1335 & 1291 & 13.65 \\
\hline
\end{tabular}

Tabel 4.2 Hasil Kecepatan Lari setiap per $10 \mathrm{~m}$ dalam lari $100 \mathrm{~m}$

Dari hasil data tersebut, dapat dilihat nilai rata-rata dari hasil kecepatan lari setiap per 10 meter dalam lari 100 meter. Berikut nilai rata-rata $0-10 \mathrm{~m}$ yaitu $1.73 \mathrm{~m} / \mathrm{s}, 10$ $20 \mathrm{~m}$ yaitu $1.42 \mathrm{~m} / \mathrm{s}, 20-30 \mathrm{~m}$ yaitu $1.24 \mathrm{~m} / \mathrm{s}, 30-40 \mathrm{~m}$ yaitu $1.26 \mathrm{~m} / \mathrm{s}$, $40-50 \mathrm{~m}$ yaitu $1.26 \mathrm{~m} / \mathrm{s}, 50-60 \mathrm{~m}$ yaitu $1.34 \mathrm{~m} / \mathrm{s}, 60-70 \mathrm{~m}$ yaitu 1.26 , $70-80 \mathrm{~m}$ yaitu $1.33 \mathrm{~m} / \mathrm{s}, 80-90 \mathrm{~m}$ yaitu $1.25 \mathrm{~m} / \mathrm{s}$, dan $90-100 \mathrm{~m}$ yaitu $1.25 \mathrm{~m} / \mathrm{s}$.

Berikut mengenai hasil penelitian kecepatan pelari lari jarak pendek $100 \mathrm{~m}$ :

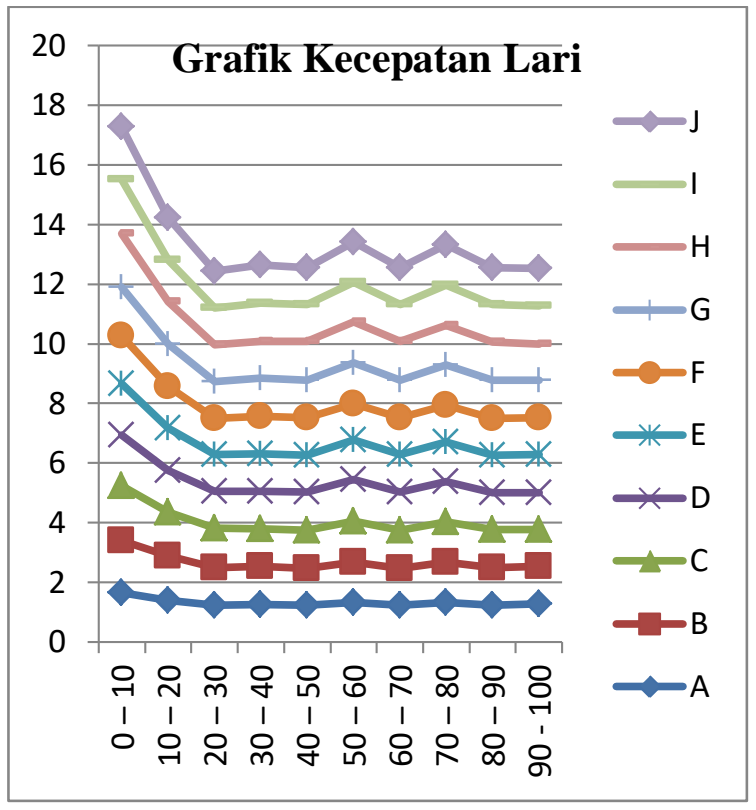

Gambar 5. Grafik Kecepatan Lari 100 meter setiap 10 meter

Dilihat pada grafik kecepatan setiap per 10 meter dan waktu tempuh 100 meter, terdapat beberapa temuan diantaranya, kecepatan setiap per 10 meter semua subjek cenderung semakin menurun dari mulai start hingga finish, pada waktu tempuh 100 meter pelari tercepat, jika kita analisis dari grafik kecepatan setiap per 10 meter, pelari tercepat memiliki kecepatan yang konstan (tidak fluktuatif) pada setiap jarak 10 meter.
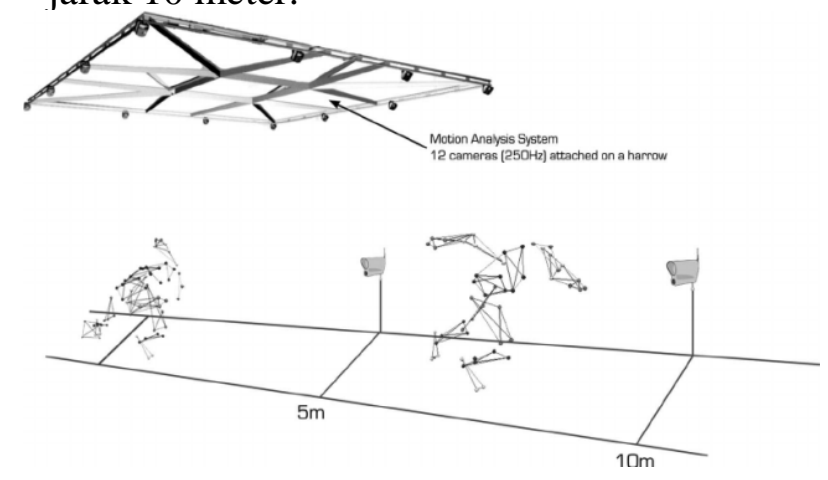

Gambar 4.6. Motion Analysis Lari (Sprint) 100 meter 


\section{KESIMPULAN DAN SARAN}

Dari sejumlah penelitian yang dilaksanakan diperoleh sejumlah kesimpulan sebagai berikut:

1. Sport Science hadir untuk mengadakan tes monitoring, evaluasi, dan pengendalian latihan olahraga prestasi.

2. Pelari dapat melakukan percepatan (akselerasi) pada jarak 0-50 meter dengan nilai rata-rata percepatan (akselerasi) yang dilakukakn pelari yaitu $1.23 \mathrm{~m} / \mathrm{s}$, dan pelari kembali melakukan percepatan pada jarak 80-90 meter dengan nilai rata-rata percepatan (akselerasi) yang dilakukan pelari yaitu 1.23 $\mathrm{m} / \mathrm{s}$.

\section{SARAN}

Beberapa saran yang bisa penulis sampaikan berkaitan dengan penelitian yang telah dilakukan sebagai berikut:

1. Pemanfaatan kinovea video analysis software untuk menganalisis gerak segera disosialisasikan kepada para pelatih khususnya pelatih lari.

2. Perlu dibangun laboratorium biomekanika untuk analisis kecepatan gerak, khususnya dalam lari lintasan sehingga penampilan atau prestasi atlet akan menjadi lebih baik.

\section{DAFTAR PUSTAKA}

Bartlet, Roger. (2007). Introduction to Sports Biomechanics (Analysing Human Movement Patterns)

Crespo, Miquel, Dave and Miley. (1998). ITF advance manual. Roehampton, London: ITF.
Hidayat, Imam (2003), Biomekanika, Bandung: FPOK-IKIP Bandung Ismail, IsmayantoBenny. (2014). Hubungan Panjang Langkah Dengan Kecepatan Lari Sprint 100 Meter Mahasiswa Program Studi Penjaskes Semester Vib Fkip Universitas Bengkulu Tahun Akademik 2013 - 2014. Skripsi. Universitas Bengkulu. Tidak Diterbitkan

James. G. Hay (1985), The Biomechanic of Sport Techniques, Prentice Hall Englewood Cliffs, New Jersey.

Marhento,Putut. (2000). Majalah Ilmiah Olahraga. Yogyakarta : MAJORA Volume 6 Edisi April 2000.

Rahmat, R, Rusdiana, A, dan Supriatna, A (2015). Pengembangan Alat Ukur Kecepatan Lari Berbasis Microkontroler Dengan Interfacing Personal Computer. Jurnal Terapan Ilmu Keolahragaan 2015 Vol.02 No.02 Halaman 34-39

Rumini, 2004. Model Pembelajaran Atletik dan Metodik 1, UNNESSodarminto. (1992). Kinesiologi. Jakarta; DEPDIKBUD DIRJEN DIKTI. 